\title{
Article
}

\section{The Role of STEM Program Directors in Broadening the Impact of STEM Interventions}

\author{
Ana Karen Gomez ${ }^{1, *}$, Krystle Palma Cobian ${ }^{2}$ and Sylvia Hurtado ${ }^{1}$ (D) \\ 1 School of Education and Information Studies, University of California, Los Angeles, CA 90095, USA; \\ Sylvia.hurtado@gmail.com \\ 2 Fielding School of Public Health, University of California, Los Angeles, CA 90095, USA; cobiank@ucla.edu \\ * Correspondence: agomez0925@ucla.edu
}

Citation: Gomez, A.K.; Cobian, K.P.; Hurtado, S. The Role of STEM Program Directors in Broadening the Impact of STEM Interventions. Educ. Sci. 2021, 11, 742. https://doi.org/ 10.3390/educsci11110742

Academic Editor: Eleanor Dommett

Received: 1 September 2021

Accepted: 9 November 2021

Published: 17 November 2021

Publisher's Note: MDPI stays neutral with regard to jurisdictional claims in published maps and institutional affiliations.

Copyright: (c) 2021 by the authors. Licensee MDPI, Basel, Switzerland. This article is an open access article distributed under the terms and conditions of the Creative Commons Attribution (CC BY) license (https:// creativecommons.org/licenses/by/ $4.0 /)$.

\begin{abstract}
STEM transformation has been a longstanding goal for higher education institutions who not only wish to maintain global economic competitiveness but most recently have also aimed efforts at achieving STEM equity. While researchers have typically looked to students' and faculty's experiences for answers, STEM program directors possess great insight from working closely with students in both faculty and administrative roles. This study explores the views of 45 STEM program directors at 10 institutions across the U.S. that had high STEM bachelor's degree-completion rates relative to similarly resourced institutions. We document the lessons and strategies that STEM program directors have used to broaden institutional impact, including demonstrating their program's efficacy through assessments and evaluations, coordinating, and streamlining efforts to ensure program efficiency and longevity, incentivizing support for labor, and consolidating support from institutional leaders. We also disentangle the roles STEM program directors play as grassroots leaders or institutional agents, distinguishing them by their authority and decision-making power and by whether they work to transform the institution to better serve students or to transform students' behaviors to adapt to the institution. Our findings provide avenues to leverage STEM program directors' efforts in order to move toward STEM education transformation in higher education.
\end{abstract}

Keywords: STEM education; equity; diversity; institutional change

\section{Introduction}

Higher education faculty, staff, and administrators who advocate for, support, teach, mentor, and train historically excluded individuals in science, technology, engineering, and mathematics (STEM) have been instrumental in the retention and career advancement of many under-represented scientists. Yet, the vision and responsibility of organizing faculty, staff, administrators, and resources toward a coordinated effort to support students within a higher education institution, college, or department is often led by a STEM program director (PD). Ranging from principal investigators of grant-funded STEM diversity initiatives to administrators of institutionally-budgeted math/science tutoring centers, STEM PDs play a significant role in advancing STEM equity because of their often overlapping involvement in teaching, research, program planning, and mentoring, coupled with their local knowledge and insight of their student populations' needs [1]. Despite being the main organizers and drivers of STEM equity efforts on college campuses, little is known about their perspectives, challenges and strategies for success in achieving their aims to develop talented scientists from underserved communities. With estimates ranging from 105 to 154 federally-funded STEM initiatives in the U.S. administered by up to 15 agencies, constituting USD 2.8 billion to USD 3.4 billion of federally-funded investment alone in 2018 [2], STEM PDs play a crucial role in determining how to convert financial resources into successful student outcomes. At the same time, STEM PDs encounter challenges due to changes in funding over time, diverse sources of funding, and the impact of funding on staffing and program delivery [3]. Since STEM PDs face significant organizational 
challenges, lessons from STEM PDs are critical to improving national efforts to achieve equity goals in STEM training and career development.

Considering how STEM intervention programs often must seek legitimacy from their respective departments, college, and institutions to secure financial and program sustainability [3], forms of support, strategies for achieving aims, and challenges of STEM program directors are critical to understand in order to inform future efforts of current and emerging STEM intervention programs. Further, as government agencies and higher education leaders pivot away from previous interest-convergence narratives of increasing diversity in STEM majors to maintain global economic competitiveness [4], and toward broader projects focused on achieving STEM equity $[5,6]$, we became interested in how STEM program directors are positioned for transformative change on their campuses. In an effort to understand the perspectives of STEM program directors who play a key role in advancing STEM degree production success, the specific research questions guiding this study are:

1. What types of support do program directors for STEM intervention programs receive?

2. What do STEM program directors see as key strategies for broadening overall institutional impact?

3. What challenges do STEM program directors face, and why do they continue to do this work?

\section{Literature Review and Guiding Framework}

Program directors have been discussed in the literature typically in one of two ways, as grassroots leaders [7-11] and as institutional agents $[12,13]$. There are notable differences between these categories, both conceptually and in practice. The underlying factors that distinguish these roles are: (1) authority or the lack thereof and (2) working to change the institution to better serve students' needs or working to change students' behaviors to adapt to the existing system and better navigate the institution. Program directors who have authority and socialize students to navigate the existing institutional structure can be conceptualized as institutional agents [12]. They advocate for students and empower them, often by creating access to social capital, for example, by connecting students to faculty colleagues who can provide enriching academic and professional opportunities. However, they do not necessarily expect the institution to change its existing structures, policies, or procedures, which can present detrimental obstacles to students' success. In contrast, program directors with limited formal authority who continue to work to change institutional structures despite the barriers, obstacles, and limitations they encounter are best described as grassroots leaders [7]. They take leadership in advocating for institutional changes to develop pathways for student success.

This study fills a significant gap in the literature by drawing attention to STEM program directors' experiences and perspectives in order to incentivize recognition and support for their important student and institutional work in STEM disciplines. Program directors are often unacknowledged in the literature on faculty leadership and institutional transformation, which tends to focus on faculty with formal positional authority, such as those who serve as department chairs for example [14-16], or those who are involved with presidential initiatives [17], and as a result embody authoritative leadership. In contrast, the work of many program directors often goes unnoticed because they typically work closely with students or mobilize others behind the scenes.

\subsection{Grassroots Leaders}

Grassroots leaders are individuals who work from the bottom up to initiate change and bring visions of institutional transformation to life. Such initiatives are often initiated in response to issues grassroots leaders witness firsthand [7]. Faculty enact roles as grassroots leaders when they respond to the needs around them by creating a vision, developing a network or coalition, and planning and organizing multiple campus agents for change. For example, a grassroots leader could identify a class with low pass-rates and create an 
innovative curriculum delivery model that is used broadly across campus, engaging others in supporting the change [7]. Such leadership takes great effort and cannot be carried out alone in an effective manner.

\subsubsection{Challenges Grassroots Leaders Face in Their Institutional Change Efforts}

Program directors possess valuable insight about how policy changes, the history of programs, and collaboration efforts have worked together to shift a campus toward success in STEM baccalaureate degree productivity. Unfortunately, grassroots leaders often encounter lack of support since the changes they seek do not typically align with others' agendas, and they must, therefore, operate outside of the system [7]. Grassroots leaders may also encounter power dynamics in the forms of oppression, silencing, controlling, inertia, and microaggressions, which can lead to burn out, turnover, and lack of leadership initiatives among faculty over time [7].

Indeed, leadership efforts among faculty are becoming increasingly more difficult for several reasons apart from the power dynamics they must navigate. An increased workload (i.e., publications, external grants, teaching, research, and service), involvement in leadership left out in non-tenure track faculty contracts, and academic capitalism, which incentivizes external privatized work, such as external grants, to subsidize pay [7]. All are factors that make it difficult for faculty to get involved with leading STEM efforts. Yet faculty leadership is gravely important because it allows for innovation, advances in knowledge, improvements in teaching practices, and alterations to policies and practicesall of which improve the learning environment conditions and broader efforts to increase diversity in STEM.

\subsubsection{Support for Grassroots Leaders Seeking Institutional Change in STEM}

Those grassroots leaders who do persist in their change efforts report drawing upon networks, establishing accountability structures, and flying under the radar to navigate power dynamics [7]. Findings from a study of grassroots leadership efforts for science education reform in higher education suggest that while not always necessary in order to achieve aims, faculty grassroots leadership can be bolstered by high level administrators [10]. Since grassroots leaders often do not hold positional authority, their change efforts rely heavily on support from individuals who have authority within the institution. Supporting grassroots leaders requires a combination of policies, practices, and values that together transform an institution's larger culture [7]. This type of institutional transformation must occur at the departmental level, across disciplines, and campus-wide in order for change efforts to have a lasting impact. When given support, grassroots leaders are likely to develop strategies and support systems that other individuals cannot due to their simultaneous faculty/administrator roles at varying levels of the institution. Institutional agents are well positioned to mobilize support for grassroots leaders, including establishing campus networks, providing internal funding, counting leadership efforts as service towards tenure and promotion, and providing more flexibility and autonomy for faculty grassroots leaders $[7,18]$. However, they may not perceive the need for systemic change and instead focus their efforts on supporting students within the existing institutional structure [7].

\subsection{Institutional Agents}

In contrast to grassroots leaders, institutional agents are conceptualized as individuals in positions of power who use their cultural, human and social capital to direct resources to students from marginalized backgrounds [12]. In Stanton-Salazar's work, institutional agents were non-family adults in reasonably high-status authoritative positions who empowered adolescents and helped them acquire resources to propel their social and educational development [12]. Applied to the current study, the role of institutional agents highlights some program directors' ability to direct valuable resources to the students they serve due to the positions they hold. For example, a study on STEM intervention 
programs confirmed the critical role of institutional agents who possess the power to enact changes, mobilize support, and secure funding sources [18]. When pressured by an alumna who worked as a corporate executive in the health sciences and donated regularly to the college, one of the program directors (who was also a dean) quickly garnered support to develop and implement a program to provide professional development to undergraduate women in the health sciences [18]. While some studies of institutional agents in STEM conceptualize institutional agents to be faculty and advisors [14] or initiators of STEM intervention programs [19], we focus on examining the extent to which STEM PDs embody characteristics of institutional agents as defined by Salazar.

Institutional agents' relationship to students serves as a form of social capital and, consequently, as a form of resistance, given the existent social stratification that distributes resources and networks inequitably along socio-economic and racial/ethnic lines [12]. Because marginalized students typically would not have access to a network of rich opportunities and resources (unlike students from dominant backgrounds), institutional agents positively alter marginalized students' mobility and serve as countervailing forces that support them in building networks of authentic social and institutional support. In order to be effective, institutional agents must themselves engage in continuous networking that results in robust and diversified social networks, which program directors are well positioned to do, since they often communicate and collaborate with multiple departments to administer their programs.

\subsection{Transforming the Student vs. Transforming the Institution}

While grassroots leaders seek to transform the institution to better serve students, institutional agents seek to transform students so that they are agents of change in their communities and in their own lives [12]. Although Stanton-Salazar claims that institutional agents are not interested in helping students conform to the established social order, in seeking to change students' behaviors rather than the institution's, the status quo is maintained. For example, Stanton-Salazar draws upon the concepts of bonding and integration to theorize how institutional agents can foster socialization processes that allow students to adhere to the "educational system's moral order and ideological foundations", which clearly suggests advocating for students to conform to the educational institution [12] (p. 1082).

In the literature, institutional agents are theorized to support students to conform and navigate the existing institutional structure through four main roles: direct support, integrative support, as system developers, and through system linkage and networking support [12]. Direct support involves institutional agents' efforts to direct resources, mentorship, and knowledge towards students, for example by advising students academically or helping students learn how to network. Integrative support describes institutional agents' ability to coordinate students' social integration in high-status professional networks that can lead to career opportunities. As system developers, institutional agents create programs that connect students to support, resources, and opportunities. Lastly, institutional agents provide system linkage and networking support by actively recruiting students into programs or departments, which often involves serving as bridges to gate-keepers through person-to-person introductions. For example, in a case study of four Latinx STEM faculty, Bensimon et al. found that they cultivated the success of Latinx students whose talents could have remained invisible to faculty members more prone to evaluating student success by traditional measures of merit, such as high performance on exams [13]. By inviting these students to participate in research labs, recommending them for STEM programs, and mentoring them, these faculty members were using their position, status, and authority (i.e., they all had tenure and were full professors) to cultivate students' success within the institutional structures in place. 


\subsection{Epistemology}

Given our study's focus on STEM intervention programs, we believe it is important to explain our stance in regard to the epistemological issue of STEM. Within the STEM literature, there exists widespread debate about what scientists do, think, and say and, as a result, what is important for STEM learners to do, think, and say. The prevalent model for STEM epistemology is using professional science, technology, engineering, and math as a model for STEM education. While this model allows us to capitalize on the expertise of the STEM community and establishes standard norms, it also incorrectly characterizes STEM professionals as experts and STEM learners as novices [19]. This incorrect categorization reinforces a deficit view of learners and does not take into account learners' acquired expertise from navigating and making sense of the natural world around them. Our epistemology (and that of the STEM program directors we interviewed in our study) most aligns with that of Russ [19], such that we believe STEM experts and STEM learners are engaged in the same task of constructing knowledge and making sense of the world, and thus have a shared epistemology. The value of this epistemology is in its utility for knowledge construction, and not on its proximity to epistemologies of professional science [19].

In conducting this study, it is also important to note differences in epistemological approaches in STEM research and STEM education research. We juxtapose our epistemological stance as qualitative researchers analyzing STEM program directors' experiences with ways of "knowing" in the sciences. In a constructivist paradigm, used most often in qualitative research, there are multiple truths that co-exist. Common in STEM is positivism, which aims to identify one reality and one truth. To answer our research questions from a constructivist paradigm is to emphasize participants' perspectives and views to understand the phenomenon of interest (i.e., perspectives as STEM PDs).

\section{Methods}

\subsection{Data Source and Site Selection}

The authors derived the data for this study from a larger multiple case study project, (Broadening Impact: Key Factors That Improve Diversity in STEM Research Careers), designed to examine higher education institutions that were exemplary in producing undergraduate STEM degree holders given their relative institutional resources. The larger dataset included 361 four-year institutions that had Freshmen Survey Data matched with federal data on STEM completions. Using stochastic frontier analysis [20] on 12 years of Federal Integrated Postsecondary Educational Data Systems (IPEDS) data, efficiency scores were derived by controlling for an institution's human capital (undergraduate and graduate full-time equivalent), labor resources (full-time equivalent faculty), and financial capital (revenue per full-time equivalent undergraduate), disaggregated when possible by race, to identify institutions that did better than expected at producing undergraduate STEM degrees compared to similarly resourced institutions [21]. Institutions with high efficiency scores were selected based on diversity of institutional type and availability of programs and individuals for participation. The selection process yielded 11 four-year higher education institutions: five Hispanic Serving Institutions (HSIs); two Historically Black Colleges and Universities (HBCUs); three Predominantly White Universities (PWIs) (see Table A1 in Appendix A). One institution was not included in this study because of a lack of sufficient program director interview data relative to other campuses.

A team of four-five researchers conducted site visits to interview STEM faculty, program directors, and upper-level administrators at each site who were identified as critical to efforts to advance STEM equity on campus. The number of interviews conducted at each site varied depending on the size of the institution but ranged from 25-40 per site. To identify participants, the research team performed a web scrape to extract relevant information from each campus website about STEM intervention programs and STEM equity efforts [22] and worked with a senior administrator at each site to finalize the list of relevant participants. Interview protocols elicited responses to questions regarding the 
nature of STEM support programs offered, the pedagogical approaches utilized in STEM classrooms, policies and structures that promote improved STEM teaching and learning, and how support for STEM students is coordinated (see see Table A2 in Appendix A). All interviews were audio-recorded, transcribed verbatim, and loaded into MAXQDA software for coding. All methods were carried out in accordance with relevant guidelines and regulations approved by the Internal Review Board at the researchers' campus.

\subsection{Inclusion Criteria, Coding, and Analysis}

This study focused on participants who served as directors of STEM programs (sometimes exclusively, but often in conjunction with other roles that the participant held on campus) in order to highlight STEM PDs' unique experiences in navigating institutional structures and garnering support for STEM equity. We identified individuals who were clearly directors of STEM programs established by the university to support students in STEM majors (e.g., an academic program for math majors). Where a participant's official job title appeared unclear regarding their role, the authors examined transcripts to determine the nature of the participant's role and categorized participants with heavy involvement in decision-making and program implementation as STEM PDs (e.g., STEM center coordinator). Next, the authors identified principal investigators (PIs) of grantfunded STEM intervention programs (e.g., Louis Stokes Alliance for Minority Participation, an NSF-funded comprehensive program created to broaden participation in STEM) to account for faculty members' and senior administrators' involvement in STEM intervention programs. Excluded from our criteria were faculty and/or administrators who directed programs or centers on campus that supported STEM students indirectly (i.e., academic learning centers that encompassed additional academic disciplines aside from STEM). We held meetings to parse through the details of individuals' affiliations to STEM programs, and once consensus was reached, we developed a final list of 45 STEM PDs (see Table A3 in Appendix A).

To analyze the data, we employed cross-case analysis [23] in order to understand how findings for each research question varied based on each campus context. Interview transcripts were coded by a research team using open-coding [24] to inductively develop a codebook for the entire group of participants from the 10 sites. For analysis of the current study, we extracted previously-coded excerpts that related to the research questions and read through case narrative reports and research team notes from each site visit. From the original codebook developed for the larger project, we extracted the following codes for analysis: funding sources only for programs; supportive actions of administrators, upper leadership or chairs; program history, purpose, and assessment; criticism of the administration or institution. When necessary, the authors went back to the transcripts of STEM PDs to conduct additional open-coding in order to ensure we were thorough in analysis of participants' interviews. The research team then developed axial codes by narrowing larger text segments to interconnected themes and categories related to the study's three research questions: support program directors receive, challenges they face, and strategies they draw upon to persist in their efforts (see Table A4 in Appendix A). Next, the authors met and discussed STEM PD's positioning as grassroots leaders and institutional agents and determined that they could not be categorized neatly according to definitions based on the existing literature. Our findings propose two additional categories that include an institutional accomplice and the transformative leader to expand and better capture STEM PDs' role and positioning on their campuses.

\subsection{Ensuring Trustworthiness}

To ensure trustworthiness, the data were analyzed and discussed among the authors. The answers to each research question were analyzed independently, after which the derived themes were compared. Additionally, the authors wrote analytical memos [25] during the analysis stage and the entire research team met regularly over the course of five months to compare analyses, discuss different interpretations, and edit assertions until 
reaching agreement on findings that best represented the meaning and interpretation of the data.

\subsection{Limitations}

Participants' responses during data collection may have been biased by the initial framing of the purpose of site visits in that the researchers were transparent with participants about their aims to understand why their campus was exemplary in supporting undergraduate STEM degree completion. This may have biased participants to primarily focus on positive aspects of their roles and/or of the institution. In other words, participants may have withheld additional challenges and complaints within the context of their role and aims. To address this potential bias, we sought divergent cases, extracted excerpts from the code, "criticism of the administration or institution" and also went back to the raw transcripts of STEM PDs for a second round of coding with focused attention on challenges experienced by STEM PDs. Using case narrative reports, original codes, and newly created codes, we triangulated the data until saturation was reached on challenges faced by STEM PDs.

\subsection{Positionality}

At the time of the study, the first author was a graduate student researcher on the data collection team. The second author was also a graduate student researcher on the data collection team and is currently a senior research analyst evaluating biomedical intervention programs. The third author has served as a PI of an R01 grant and has extensive experience in studying STEM intervention programs. We aimed to mitigate any biases by employing strategies such as developing a systematic analysis and audit trail to document steps in thinking and theme development, especially when working with large data [26,27] in addition to taking measures to ensure trustworthiness and credibility.

\section{Findings}

The STEM program directors in this study acquired a repertoire of lessons and strategies that can be leveraged to broaden institutional impact when given the proper institutional support. The following section responds directly to the study's four research questions by discussing types of support STEM intervention program directors receive, STEM program directors' key strategies, challenges STEM program directors face, how program directors are committed to making a difference in students' lives, and program directors' positioning. The names of programs discussed in this section have been replaced with pseudonyms to protect program directors' anonymity.

\subsection{Types of Support STEM Intervention Program Directors Receive}

\subsubsection{Monetary Support}

Monetary support was frequently mentioned as an important factor that either deterred or enabled STEM program directors' efforts. Sources of monetary support included: federal grants, private foundation grants, federal funds, state funds for public institutions, private industry, and college budgets, including dean's discretionary funds, funds from the provost's office, and funds raised by university development offices. As expected, the National Science Foundation (NSF), National Institutes of Health (NIH), and Howard Hughes Medical Institute (HHMI) were the primary organizations that funded STEM program initiatives across all 10 institutions. For example, the Director of the Biomedical Research Center at Atlantic Southern State University discussed the grants that funded efforts to help minority STEM students pursue graduate education:

We have been using these grants to get minority students into graduate school and professional school ... I came in with that [grant] in 1997. That program was to build a research infrastructure here at Atlantic Southern State University. I also developed a student-centered program component whereby every faculty member that we fund to run this program must train at least two students in their 
lab. I ran that for ten years or so, maybe a little longer. Then we got another P-20.

We developed [it so] that - the student must be attached to a faculty member who's doing research. But I wasn't too happy about all that-I didn't feel satisfied. So I decided to write [another program grant proposal] [to secure NIH funding].

This program director had to seek external support to fund efforts he deemed valuable to increasing under-represented STEM students' persistence in higher education. He did not possess the power to allocate institutional funds to the efforts he deemed valuable, yet he still wanted to sustain change in response to a necessity he witnessed-lack of research opportunities and graduate school mentoring for minority STEM students. He took the initiative to seek external funding, develop programs, organize faculty, and garner support to implement student-centered grant-funded efforts. His story represented that of several of the faculty we interviewed, whose program funding came from external sources. As a result, these program directors tirelessly sought funds, applying and reapplying once grant cycles ended, in order to ensure the longevity of the programs they directed.

Without commitment from institutional funds, the stability of these programs was always uncertain and dependent on whether more grants could be obtained to keep the program operating. Several program directors utilized a combination of funding sources to support their work; however, a few were selective about where they sought funding in an effort to increase the program's impact. One program director at Southern Private University shared why their funding only comes from the institution's Natural Sciences Department:

I think it's come up in the past, well, maybe we could get a bigger budget if we asked for it over here, but we've never wanted to because keeping the funding here keeps the math lab close to the math classes, and then our faculty, and we were just-we were scared that maybe if the funding came from somewhere else, that would tie it to the library where the writing center is, but we don't really want [our program] to be that far away from the math faculty and the math classes.

Receiving monetary support carried implications, since funders often placed constraints, contingencies, and other regulations that affected the execution of the program being supported. Therefore, program directors frequently had to negotiate funding sources and weigh the benefits of receiving funding from particular sources at the cost of relinquishing decision-making power, such as where the program would be housed in this case. The math laboratory's location in the example above was an important aspect of ensuring accessibility for the program's target population: students enrolled in math classes and faculty teaching those math classes. Therefore, even though this program could have received funding from other sources within the institution, the director decided to secure funding solely from the Natural Sciences Department to ensure its proximity and institutionalization as part of the math department. This program director discussed the importance of considering the effects of accepting different funding sources and of having a clear vision of the program's mission, in order to not lose sight of what is truly necessary to accomplish that purpose. In this case, knowing the program's purpose helped the program director realize that while additional funding was needed, the highest priority was remaining accessible to the program's target population and ensuring institutional commitment.

\subsubsection{Non-Monetary Support}

Non-monetary sources of support were equally, if not more, valuable for ensuring the maintenance and expansion of STEM programs on campus. Some non-monetary sources of support frequently mentioned by program directors included: community support from local or state businesses, non-profit organizations, and tribes; dedicated institutional agents, such as faculty and staff that served as allies; productive collaboration with other programs and offices on campus; support from senior leadership. With respect to senior leadership support, two institutions in the study had college presidents who were 
extremely supportive of STEM efforts and showed great support for STEM transformation initiatives. Nonetheless, faculty at these institutions were still described as the main drivers of transformation since their efforts ensured the endurance and successful implementation of senior leaderships' initiatives. One program director from the University of the Southeast shared the importance of faculty's efforts paired with administrative support:

It really has to be bottom up to be successful. But it has to have top level support ... Because if you don't get the faculty committed to do it, it's never going to happen. I don't care how much money you throw at it. You can throw an infinite amount of funds and if the faculty aren't committed to doing it and aren't willing to change, it's not going to happen. So I see all these big programs across the country where people have thrown lots of money at trying to increase the numbers of underrepresented minorities in science ... I feel like what we're doing is really having a pretty substantial impact and it's mostly because it's bottom up and the faculty are committed to making it work.

Program directors proved to be valuable assets to the institution since they mobilized faculty and other individuals at the institution to support important initiatives. Without the work of these program directors, the money invested into programs would likely not result in effective, enduring programs that contribute to the institution's long-term STEM transformation.

At institutions where serving students was an integral component of the university's mission and campus culture, program directors received support from faculty more rapidly. In the Geosciences Department at Central Plains State University, faculty decided that each of them would enlist undergraduate students to help in their labs because they recognized the value of the type of hands-on learning that occurs in a lab. The program director discussed the positive effects of this faculty commitment:

This is a commitment that the faculty recognize is really important for our undergraduate students, so everybody, every single faculty in this department has an undergraduate student working with them ... We decided that it was a good idea because we are committed to student success and student learning, and we feel that one of the best ways for the students to learn is through exploration learning by working in the labs.

Initiatives rely heavily on the support of faculty implementation, which sometimes needs to be incentivized if it is not an existing commitment. However, the institution also plays a critical role in removing financial barriers, which allow the programs to continue to function adequately. As such, it is pivotal that institutions realize their responsibility in supporting program directors at their institution, which largely benefits the institution at large due to the positive effects programs have on students, including increased retention rates, sense of belonging, and career preparedness.

While not a specific person or entity of support, the role of culture and historical context also supported program directors' capacity for change. For example, the compositional racial/ethnic diversity of some institutions, or the reputation of other institutions for being deeply connected to their community, facilitated programs' abilities to target under-represented racial minorities and obtain buy-in from both institutional leadership and the community. Additionally, program directors at the two HBCUs in this study described the legacy and reputation of serving black students as critical to being able to make the argument to leadership and funders to invest in becoming national leaders in STEM intervention efforts. When asked about how working with under-represented students has shaped notions of student achievement, the STEM program director at Atlantic Southern State University stated:

When I was a minority student in an HBCU, I was a MARC scholar, and I was so interested in going into the sciences. So, my first thought when I became a faculty member was to seek out minorities and train them. As a matter of fact, that was the reason why I came here because I was going to University of Kentucky, 
Lexington to teach in their School of Medicine and I decided to come here. So, my goal was to train minorities so that they can have these leadership positions in the research enterprise ... I think training minorities since I've been here in 1997 has given me joy and it has given me the opportunity to give back to the very community that raised me.

The type of motivated commitment to minority student success that this program director describes is not something that is demonstrated among all faculty. He clearly expresses having been in his students' shoes and now finds joy in being able to create access for them. This program director ultimately chose to work at an HBCU because he knew that the institution's culture mirrored his own values and he would, therefore, receive support for program development efforts.

\subsection{STEM Program Directors' Key Strategies}

\subsubsection{Demonstrate Your Program's Efficacy}

In cases where programs were directly funded by the institution, program directors described having to continuously justify why their program was a beneficial investment for the institution. Garnering this type of buy-in was especially necessary when institutions were undergoing departmental evaluations or when institutional budgets became constrained. A math professor and math lab director at Southern Private University explained:

We always have to be vocal about protecting and supporting [our program] and saying, 'This is worth it. Yeah, it's expensive. Yeah, it takes resources, but it's what actually sets us apart and makes us interesting.' As higher education changes, as budgets become tighter, as administrators look for ways to streamline, it's constantly going to come under fire, and we're constantly going to have to justify [the math lab and programming associated with] it.

One of the ways this program director justified funding the university's math lab was by showing its efficacy. For example, he maintained a record of how many students utilized the math lab, how many presented and published their research, and other markers of success. Additionally, he mentioned how something as seemingly insignificant as attaching "buzzwords" (e.g., high-impact practice) to program descriptions and grant narratives was an effective way of garnering support both from external funding sources and administrators who were more likely to invest in high-profile efforts.

Several program directors discussed the importance of demonstrating their programs' efficacy through the assessment and evaluation of their high-impact practices, such as tutoring programs, peer mentoring efforts, and involving students in research labs to name a few. In fact, some program directors were hired primarily because of their ability to conduct assessments, generate reports documenting retention rates, and use data to depict the success of their program, as well as highlight areas of improvement. The Director of the Engineering Program at West Coast State University discussed the importance of demonstrating a program's success through data-driven efforts:

The programs that didn't survive what I know and I can tell you personally, is that they were not able to demonstrate their efficacy. Here, we have a very strong assessment. So we're able to demonstrate why your HIPs [high impact practices] work and what did you do and how did you measure success, what is the data you collected, what is your interpretation? You become more credible.

Providing evidenced-based information about a program's efficacy ensured continued support from the institution. The Engineering Program at West Coast State University survived in large part because of its strong assessment practices. The Dean at West Coast State University increased state fund allocations since the program was improving its students' STEM graduation rates and, in turn, increasing the institution's overall graduation rates. While demonstrating a program's success might seem like an obvious strategy, it did not prove to be an easy feat to achieve. Oftentimes program directors did not have adequate software to track students, monitor their progress, and gather data to confirm the 
effectiveness of their programs. In such cases, the role of institutional agents (e.g., deans) in serving as mediators to access resources and funds to carry out program evaluations became invaluable.

\subsubsection{Coordinate and Streamline Your Efforts}

Successful outcomes often occurred when there was a concerted effort to coordinate introductory course curricula and pedagogy, institutionalize practices in the event that an influential change agent left the institution, and continually apply for grants. For example, one program director proposed a way to coordinate change efforts at Northern Mountain University:

I'd like to see someone at the upper level of the administration who's calling sort of regular meetings of those coordinators, and then the actual grant writers for the programs, and the program directors too. But again, it's just, you know, faculty are like a herd of cats. And so, if somebody doesn't say, 'We're going to have these meetings regularly to discuss,' then they've all got other things to do, you know, myself definitely included.

Program directors expend ample energy coordinating and streamlining initiatives; they mobilize others, bringing together individuals in different roles at the institution and ensuring that those involved work effectively together. Given their experience at the institution, they often possess valuable insight on the history of the institution or programs within it, and as a result are able to provide strategies to ensure maximum efficiency. However, as the program director from Northern Mountain University described program directors who simultaneously serve as faculty have huge workloads that can impede them from coordinating efforts, especially those that are not supported by the institution and require more planning. Institutions could contribute greatly to program directors' efforts by providing support in the form of funds and resources, connections to campus networks and partners, and even promoting the program efforts campus-wide to gain more traction and buy-in.

In the case where program directors did not receive support from the institution, they had to focus on efficiency and quality over quantity to ensure that their efforts were not wasted. For example, the Program Director of the NSF STEM program at Midwest State University discussed his strategy as not trying to meet every student's needs but rather connecting students with existing programs to meet needs that the STEM program did not fully address:

That's a real strength of [the program], that they aren't always trying to offer every - they're not trying to meet every student need themselves-but in a lot of cases are making sure that students are aware of different things that are on campus that can help them meet some of the needs that [the program] isn't directly addressing.

In this way, program directors serve as bridges between students and other programs to create a support network at the institution. As mediators, program directors must maintain strong ties with individuals across campus, in order to refer students and provide current, accurate information about the services that other programs provide.

\subsubsection{Incentivize Support for Labor}

Program directors often expressed frustration over not having enough time or resources to do their jobs and not having more people on board to help with STEM interventions. On some campuses, even though ideological support for initiatives was widespread, those who were actively involved were few and could be overburdened. A program director from West Coast State University expressed this concern saying:

Even if you don't want to work with students, just more faculty-student interaction from everyone, not just the same faculty, over and over would create a more 
cohesive community. Again, I think it's something that everyone is supportive of as an idea. They just don't all do it.

A program director from Southern Private University also noted a discrepancy between ideological support and how it translates into action:

So I think everyone agrees research is important, going to conferences is important, but the load disproportionately falls on the few who are willing to actually do that. I think everyone supports it and thinks it's a great idea, but we need to either spread that load evenly throughout the department or figure out a way to credit the time and effort it requires for it to fall on only a few faculty before we get burnt-out.

It is important to note that program directors did not view support for their labor as a bonus, luxury, or reward, but rather as a necessity to achieve their mission of serving students, especially those from marginalized backgrounds. Without support, either from other faculty to share the workload, or from administrators to compensate or credit their labor, program directors' efforts would eventually decline or come to a halt. Numerous faculty conveyed a concern of burning out and worried about the longevity of programs they were involved in. They noted some ways the institution could effectively support their efforts, including providing institutional funding after the end of a grant, financial support from encouraging deans, and changing tenure/promotion requirements to reward their leadership and service efforts.

\subsubsection{Consolidate Support from Institutional Leaders}

In order to gain institutional support, some program directors made a concerted effort to meet with deans at their institution and inform them about their programs; the Director of the Center for Environmental Professionals at Northern Mountain University shared:

I've gone to all the Deans, I've talked to all of them, told them who we are. The President is very well aware of us now. I asked for a promotional video four years ago, we're working on it now. So it's things like that, that you kind of have to like say, okay, 'We're here and we're helping you meet your goal number six, which is to become the leading university serving tribes'.

Being able to demonstrate how the program aligned with the institution's strategic priorities was a clever strategy that resulted in support from those in positions of authority who could allocate funds and garner traction across the institution for the program.

Another strategy to incentivize an institution to support a program is to demonstrate how the program's outcomes align with state mandates. The Director of the Math Program at Southeast State University discussed how this strategy helped institutionalize the program's efforts:

The other thing that happened was the state decided that we would be funded based on our performance. So when that happened, the University decided to find out where were the roadblocks to first to second year retention and that's where those critical classes come in. So the roadblocks to first to second year retention in first time college students turns out to be pretty much clustered around seventeen classes, with math having five of them, which is one of the reasons it's so important. ... STEM transformation became institutionalized; so we were no longer just dependent on a funded project to transform courses, a lot of efforts that were institutionalized began as external grants. That's the expectation, the state mandate pushed the institution to work towards this and to start investing, too, because it was going to benefit them and they began to see actual results: students not failing classes [as a result of the program].

The Math Program at Southeast State University was successful in improving students' pass rates for introductory math classes, which initially had some of the lowest pass rates among first year students. The institution was already looking for a way to address first to 
second year retention rates because of state mandates that tied the institution's funding to performance. Therefore, when these goals converged, the institution was incentivized to support the Math Program and institutionalize it so that they were no longer dependent on external grants to continue operating. Having the institution's financial and operational support allowed the Math Program to serve more students and to have a larger impact on the institution. It also alleviated the stress and worry of potentially losing funding in years to come, jeopardizing the program's future.

\subsection{Challenges STEM Program Directors Face}

4.3.1. Inadequate Infrastructure and Facilities

Some program directors had moved past the hurdle of securing funding from grants but still had to face the challenges that came with implementing their initiatives. The Director of the Geosciences Program at Southeast State University was constrained by the institution's limited infrastructure, which did not support the active learning practices he sought to implement:

Program Director: I see a lot of people promote it [active learning] saying that you can do this team based learning type of stuff in a class of 150 where the chairs are all fixed in there, and I just don't see how it works. It's just not effective. I tried it last fall in a general physical geology course, and it just seemed like-with learning assistants that part was awesome, but you had this big class — you had this big theatre-type sitting with no aisle in the middle, and you couldn't get to help the students. It was just too difficult.

Interviewer: So, the infrastructure of the actual classroom space can be a barrier $\ldots$ ?

Program Director: Yes that's right. And so often the classrooms generally are not designed for this. It's very rare to get a classroom that just has tables in it. Almost-there is always the fixed desk type of thing, and so if you want to have students actually doing problems, they don't have that workspace.

The institution's facilities were a real barrier for efforts to improve STEM teaching and learning at Southeast State University. In order for these strategies to be implemented, the institution would have to invest substantial financial resources to redesign its classrooms. In the meantime, this program director could not fully execute his vision for STEM transformation at the institution.

\subsubsection{Lack of Support for Equity from Administrators}

While time and time again the program directors we spoke with were noticing areas that needed to be improved and mobilize change efforts, some had come to realize that if the upper-level administrators were not on board, they would have a very difficult time carrying out their vision. The Director of the Academic Center, which houses the STEM program at Southeast State University shared this perspective:

It's from the top down. Whatever's happening at the time, it was the provost, now the chancellor, going down to the dean, the dean and their administration, so it all trickles down. It all trickles down. If the leadership isn't with it, ... If your leadership isn't pro minority, low income, first generation students, then where are we in this whole game?

This program director knew the importance of having the institution's administration on board with program initiatives, especially those involving equity and serving marginalized students. Researchers have found grassroots leaders experience resistance toward equity initiatives more broadly compared to other initiatives [7-9]. Similarly, another program director at Northern Mountain University discussed the importance of having an explicit commitment to serving under-represented students, in his case Native American students at an institution that collaborates with Tribal colleges and universities: 
But if you don't have the commitment, then you wouldn't even think about doing anything special for anybody, right? But if you have a commitment that here's a group, we live in the midst of this population and we are to be committed to serving this population. Once you have that explicit commitment and it becomes part of your [institutional] mission, then obviously, you think about all kinds of different ways and means how can we now enact this commitment.

This institution explicitly committed to serving the Native American students that composed a large portion of its student population. Having a clearly defined mission allowed the university administration to support this program director's efforts, which aligned with the institution's priorities to serve Native American students.

Gaining administrative support was challenging for program directors across all 10 institutions, including those whose programs were not specifically dedicated to serving diverse populations. For example, the program director of the Science Living Learning Community that was created with a grant from NSF at Southern Private University discussed the challenges he faced with senior administrators who had different views about how he should design his program:

I'm running into obstacles, okay? There are people at the lower levels that are very supportive. It's senior administrators that have been causing the problem, and I cannot overrule decisions that they make, so I have to make do. It depends on who's there. It depends on how flexible that person is willing to be. If it were me, knowing what I know about what has happened with this program, I would say, 'Okay, we have this model, but you can continue with your model, because it's working, as far as I know'.

Even though this program director was the principal investigator of a grant, the administration at Southern Private University ultimately had the power to make decisions, even if they ran contrary to what the program director envisioned. Without administrative support, change could be deferred, as a director of undergraduate studies for the college of engineering, architecture, and computer sciences at Mid-Atlantic University discussed:

I guess that's where it comes with administrative support. If I wasn't the one in this position ... if the person in this position supported that kind of thing, rapid change that doesn't have to go through committee and process, perhaps that too would help change to occur at a much more rapid rate ... you have to have support at the right levels.

When asked what administrative support would look like, this program director shared valuable insights about how administration can support faculty and staff to promote institutional change:

I think in some ways, it could literally just be encouragement, and not having to do things the same way that we've always done them, because there doesn't seem to be need for change necessarily. [Chuckles] Whether that be perceived or data-driven need. Encouragement to do these kinds of things. It could also be of course financial support to attend these kinds of conferences where you can have these kinds of exchanges and find out-especially in STEM areas ... maybe requiring, to the extent that you can require, but making the promotion and tenure process look more favorably upon those kinds of conferences are presenting papers for those kinds of proceedings ... As you put out newsletters, or you have faculty meetings, and you theme things, making sure that student development is one of those themes, whether it be the weekly newsletter theme, or the faculty meeting theme.

This Mid-Atlantic University program director believed that institutional agents and administrators played an important role in supporting program directors' efforts. He envisioned institutional leaders welcoming and encouraging innovation instead of being resistant and viewing changes as unnecessary, providing financial support to programs, 
rewarding faculty participation in conferences dedicated to student development, and embedding thematic discussions into departments' routine functions, such as faculty meetings, newsletters, and orientations.

\subsubsection{Being Understaffed and Underfunded}

In addition to challenges associated with navigating power dynamics among administrators, program directors also experienced difficulties with being understaffed while serving a student population with various needs. A program director that oversaw various programs at East Coast State University shared:

We can always use more staff. [Laughter]. If you do the calculation between the ratio of students to a counselor, it's still quite high at about 150 to 160 students per counselor, so that ends up being high because not only do they see students all day, they also have some administrative functions that they do as well. It's always great to have more counselors on staff, but we are limited to four. That's one obstacle. The other obstacle is also that the trend has been that a lot of the students have a lot more mental baggage or emotional baggage that come with them, and even though our counselors are of varied backgrounds in their degrees, they are not social workers ... What other obstacles? We could always use money to do lots of things, to make things bigger or greater.

Not only did counselors have a considerably large group of students they each served, but they also had to wear multiple hats, not only as counselors but sometimes as social workers to support students with mental and emotional distress, on top of other administrative duties they were tasked with.

As expected, several program directors discussed lack of sufficient funding as one of the greatest challenges they faced in their pursuit to implement their programs in the most impactful way. For example, the program director of the Living Learning Communities (LLCs) at Southern Private University shared what would be possible if he had additional funding:

I Mthink our co-curricular programs are really great. It would always be nice to have more funding for them. When you're talking about an LLC of 98 people, you want to bring everybody, that's two busses. Pretty expensive to have two busses for four or five hours a day, right? If we had more funding-I'm assuming that you're not going to share this with my people here, that I'm whining about not having more funding, but if we had more funding, we could do a lot. I mean, Austin is a fantastic town to be able to take advantage of resources in Austin. We could really enhance that co-curricular piece.

This program director needed funding for events that were crucial components of building rapport among the students who participated in the LLCs he oversaw. The entire concept of the LLCs was built around integrating co-curricular activities into students' college experience. However, when serving 98 students, it became challenging to enhance their learning through activities that required additional costs, such as field trips.

\subsection{Program Directors Are Committed to Making a Difference in Students' Lives}

Several program directors across the 10 campuses described the great lengths they went to compensate for lack of support and funding, and when asked why they worked beyond their job description, past their paid hours, and above baseline expectations, they responded similarly: they were committed to supporting the students they served. For example, the program director of the Learning Center at East Coast State University was in charge of providing academic support to students (most often first- and second-year students) through academic coaching, tutoring, and workshops. The director coordinated with faculty, staff, programs, and departments across campus to ensure that students' needs were met. One of the greatest challenges the center faced was securing funding to continue training their student tutors and staff, since professional development was key to ensuring 
the services they provided were effective. He did not feel supported by the administration because the center had an insufficient number of staff even though they served a large student population (i.e., 9142 students). This forced the director, who was hired to build, expand, and direct the program, to have to deal with supervising the other workers when the clerical assistant left at 1:00pm each day. Whenever he sought administrative support or submitted requests for more funding, he was met with the response that the administration would convene a committee, but he never received a response to his requests. As such, he described having to work past his scheduled nine-to-five workday in order to accomplish all the tasks that were necessary to keep the Learning Center running smoothly:

In order to get everything you need done, you're actually—nine to five doesn't cover it, so you're actually doing things on the weekend, or you're doing things after hours, and you're doing things-you're doing a lot more, I think, than actually what's covered by the job description.

Even in light of having to work beyond his job description and dealing with lack of administrative support, this program director described the fulfillment and satisfaction his work brought him because he was aware of the difference he was making in students' lives:

For a lot of kids, this is their best chance for success, and why wouldn't you be here helping students, supporting students who are at that place in their life? If you can help these students be successful, raise a family, support themselves, there's so much good that will transpire from that. You won't even know, butit's really rewarding, to be honest with you. It sounds like I'm complaining, but I like what I do. I like the students that I work with. I feel rewarded by it. At the end of the day I often feel tired. I don't feel like I've wasted my time. I feel like my life and the work that I do is meaningful.

While this program director voiced critiques of the institution, they were all directed towards identifying areas of improvement for the benefit of students. He understood the life-altering impact his program had on students and wanted to maximize the program's potential.

The program director of the Center for Teaching at Southeast State University who is in charge of supporting faculty teaching through assistance with course design especially for classes with higher DFWI rates, including math, chemistry, and biology courses, also shared the importance of faculty and staffs' personal commitment to students:

... since Spring Break when we had that institute, they've been meeting for two hours every week, thinking about their redesign. And they are going to follow through regardless of anything. [The faculty] are determined and ... it turned into a really personal commitment ... if you ask them because then one did ask him at a meeting, like, like how do you see your role in terms of student success? He said, well it's everything, right ... I need to know whether students are having trouble buying the book because of financial aid, right? That is my responsibility to make sure that students do succeed. I never would have thought I'd hear faculty members say things like that ... I don't really think that there's anything that we did to make that happen. We just got to be around to sort of foster it, right? And once the people get excited about it and once they, like have that realization 'oh, there's a lot that I can do,' remarkable things happen.

This program director conveyed with great enthusiasm the change he noticed in faculty after attending a STEM Retention Conference and understanding everything they could do to support students. From then on, faculty developed a personal commitment to serving students and took it upon themselves to ensure that their needs were being met. This commitment served as a catalyst for continued change among the biology faculty at Southeast State University.

Lastly, a few program directors were former alumni of STEM initiatives. For example, the Director of the Biomedical Research Center at Atlantic Southern State University shared: 
When I was an undergraduate at [my University], I was a [STEM program] scholar. In 2007, I brought in the [STEM program] [and] since [then], I've been the program director for the [STEM program] [at this campus].

Many of the STEM PDs explained that their experiences in STEM intervention programs informed their decisions as leaders of current initiatives. The desire to give back by mentoring the next generation of leaders also motivated them to continue their work.

\subsection{Theorizing Program Directors' Positioning}

Analyzing the experiences in this study through the literature on grassroots leaders and institutional agents, we learned these two categories do not encompass the full range of program directors' positioning. We realized that aims of STEM PDs and the extent of authority they had at their institutions were two key axes of consideration. While grassroots leaders represent program directors who have limited authority and work from the ground up to mobilize transformative change, there is no category for program directors who have limited authority and only seek to support students in conforming to the institution in order to successfully navigate it. Similarly, while institutional agents represent individuals who have authority and support students to conform to the institution, a category does not exist for program directors who have authority and aspirations to transform the institution. Therefore, we theorize two additional categories for program directors that have not been previously discussed or identified in the literature. These categories highlight program director's authority (limited or present) and their aims (to transform or to conform).

The first category represents program directors who have limited authority, and such as institutional agents, are committed to helping students adapt to the existing institutional structures; we conceptualize these individuals as institutional accomplices. For example, a program director from Southern Private University described his strategy of meeting with different departments across the institution, including the Dean of Students' Office, academic counselors, and Student Disability Services, in order to find out as much as possible about particular students in his program:

We talk to each other and let them know what's going on with each of the students, like, are you having an issue with a student, and, "Oh, the student's been missing class." Is there something going on in their personal life? We communicate about those issues, too, with the departments.

While this program director was clearly concerned with ensuring students' wellbeing, he was a bridge for student issues but not focused on changing institutional structures. The STEM PD believed something might be happening in the student's life that needed to be resolved in order for the student to return to attending class on a regular basis, with the aim of helping the student adapt to the institution's expectation. This goal contrasts with grassroots leaders' aims to find ways that the institution can better serve the student (e.g., through external programs, funding, or efforts that can be institutionalized and have a systemic impact).

The second category we propose are program directors who have authority, and unlike institutional agents, use their authority to change the institution to better adapt to students' needs. In doing so, these individuals join the work of grassroots leaders and become transformation leaders. This category is similar to findings from a study that documented evidence of institutional agents using their roles to disrupt the status quo [28]. One program director in our study from Midwest State University discusses his work to mobilize institutional change to address students' needs:

Well, I can tell you from the perspective of the Office for Equity and Diversity which I represent, we are committed. We understand what our students go through. We're working hard to find the partnerships, to identify the stakeholders that can help us. That's something apart, different than the whole University administration. When it comes to equity and diversity, I believe that I'm able to 
go to the top level, to the Vice-Provosts—Vice-Provosts, Provosts, President-and say, "Listen, this is what we need".

This program director worked in the Multicultural Center for Academic Excellence and as a result had direct communication with the institution's top-level administrators. Simultaneously, this individual worked closely with students supported by the Center's programs and, therefore, understood the challenges they underwent, characterizing him as a transformation leader. He capitalized on his positional authority to create change that would address under-represented students' needs.

Our aim with these additional categories of STEM PDs is not to place these individuals in a box and celebrate one group while reprimanding another, rather we aim to provide much needed clarification to the role of institutional agent and grassroots leaders in the research literature to encompass variations identified in STEM fields. Offering more clearly delineated characteristics for institutional agents, institutional accomplices, grassroots leaders, and transformation leaders contributes to increased understanding of the ways in which level of authority and power, along with aims and goals, affect program directors' experiences, as well as their capacity to affect change on their campuses. See Figure 1 for program directors' roles across dimensions of authority and transformation.

Authority

\begin{tabular}{l|c}
$\begin{array}{c}\text { Institutional } \\
\text { Agent }\end{array}$ & $\begin{array}{c}\text { Transformation } \\
\text { Leader }\end{array}$ \\
$\begin{array}{l}\text { Transforming Students } \\
\text { Institutional } \\
\text { Accomplice }\end{array}$ & $\begin{array}{c}\text { Grassroots } \\
\text { Leader }\end{array}$ \\
\hline & Lack of Authority
\end{tabular}

Figure 1. STEM Program Directors' Positioning.

\section{Discussion and Conclusions}

The work of STEM program directors often occurs behind the scenes and goes largely unnoticed and unrewarded. This study provides a window into the stories of STEM program directors who are doing an excellent job of supporting their STEM students by providing them with resources to learn, feel a sense of belonging at the institution, conduct research, graduate, and prepare for their professional careers post-graduation.

Overall, STEM PDs reported receiving monetary support in the following forms: federal grants; private foundation grants; federal funds; state funds for public institutions; private industry and college budgets; including dean's discretionary funds; funds from the provost's office; funds raised by university development offices. Non-monetary forms of support included: community support from local or state businesses, non-profit organizations, and tribes; dedicated institutional agents, such as faculty and staff that served as allies; productive collaboration with other programs and offices on campus; support from senior leadership. Demonstrating program efficacy, coordinating and streamlining efforts, incentives for labor, and consolidating support from institutional leaders were important strategies for achieving program aims.

This study's findings about strategies of STEM PDs are similar to the recommendations proposed to improve URM persistence in STEM by Estrada and colleagues [5], which include (1) increasing institutional accountability, (2) creating strategic partnerships with 
existing programs, (3) supporting curriculum change, (4) addressing student resource disparities, and (5) engaging URM students' capacity to utilize science for meaningful, prosocial goals. The authors emphasize that the impact of the last four recommendations rests upon the first recommendation to collect data and evaluate successes and failures in efforts to reduce disparities [5].

Indeed, having robust evaluation efforts was a strategy that many STEM PDs in this, and other studies, report being helpful to obtain more support to expand their program(s). A 2018 study on STEM Education Centers (SECs) corroborated the importance of program evaluation and assessment. The Vice Provost of one of the institutions in the study used the data provided by the SEC to inform decisions and scale intervention strategies. Four out of the six institutions in the study even partnered with their office of institutional research to obtain and analyze data that could inform the effective allocation of their program resources. Evaluation efforts are also pivotal because they allow programs to prove their effectiveness and, as a result, to also secure internal funding, as was the case for the SECs [29].

STEM PDs in our study faced many challenges, including poor infrastructure and facilities, lack of support for equity from administration, and being understaffed and underfunded. By examining types of support received, strategies for success, challenges, and positioning within the higher education institution, we provide contributions to research and implications for practice.

\subsection{Contributions to Research}

This study adds to the existing literature on grassroots leaders and institutional agents by drawing clear distinctions between these roles. Grassroots leaders and institutional agents work closely with students, but with slightly different aims. While grassroots leaders work from the bottom up to transform institutions, institutional agents typically work from the top down to transform students. Grassroots leaders' efforts are often restricted by their lack of positional authority and the power dynamics they encounter, while institutional agents typically hold positions of power, which grant them human, cultural, and social capital that they leverage to support students-especially those from marginalized backgrounds-in navigating existing institutional structures. Analyzing STEM program directors' experiences through the lens of a grassroots leader [7], institutional agent [12], and their roles as an institutional accomplice or a transformation leader allows us to contextualize their support structures, the challenges they face in the midst of their efforts, and the strategies they draw upon to continue striving towards STEM transformation because of their deeply rooted commitment to the students they serve [13].

Examining the positional and contextual differences among program directors will provide valuable insight into their support structures, strategies they drawn upon, challenges they experience, and how they can ultimately work together to effect greater change. Indeed, STEM transformation requires both top-down (institutional agent) and bottom-up (grassroots leader) approaches and having multi-level support has been regarded as essential to the success of institutional change [28]. Program directors are ideally situated to not only perceive what changes need to be made but to advocate for these changes. This positioning makes STEM program directors important focal points of further inquiry when working toward STEM transformation, particularly for the benefit of marginalized students.

Future research can expand theory on leadership for STEM PDs and other directors on college campuses who have varying aims (transforming the structure vs. transforming students within the structure) and authority (high level of authority within institution vs. low). Future research can also be more specific in examining culturally responsive strategies for increasing the participation of diverse researchers in science [6]. Additionally, research on the experiences of STEM PDs based on their own social identities, particularly for STEM PDs from historically excluded groups in STEM, would be critical for understanding how STEM PDs' efforts and experiences may differ based on systemic factors. 


\subsection{Implications for Practice}

It is important to note that despite the challenges mentioned, by all objective measures, these institutions were doing better than comparable institutions in graduating students and under-represented groups in STEM fields. If program directors are able to achieve these feats, often with little support, we see a great potential for the type of transformational change that can occur at higher education institutions across the United States if only greater efforts to support program directors and their visions for betterment are put into motion.

Grassroots leaders are well positioned to remain informed about students' latest needs, yet they cannot carry out these efforts in isolation in a way that is sustainable and does not lead to their own burn out. While monetary support can always provide solutions, the program directors we spoke to identified several other types of support that they would greatly benefit from, including institutional agents counting their work towards tenure and promotion, informing the larger campus community about their efforts in order to gain greater traction and buy-in, and providing professional development opportunities to them and their staff that can ensure they continue to grow and learn in order to provide the best possible service to students. We found evidence of the need for institutional agents and administrators to support the grassroots leaders at their institutions who are working beyond their job description, oftentimes out of a personal commitment and passion to serve the students they work with. Institutional agents can provide monetary and nonmonetary support to fuel and enable program directors' efforts. This is a worthwhile investment for the institution because program directors are already coordinating people and obtaining external resources; they also possess valuable knowledge and experience about what students need, the strategies are most effective, and how to implement them. Institutional agents can also support program directors' grant writing and fundraising efforts by providing professional development opportunities that train faculty to develop the skills to carry out these fundamental activities as effectively as possible, and most importantly, not in isolation. Lastly, tenure and promotion criteria should be revised to include the type of service, organizing, and leadership that program directors perform, often without any recognition or recompense.

Foundations and funding agencies should provide opportunities for STEM PDs to connect and share resources and advice with one another. Understanding Interventions, sponsored by NIH, is an annual conference that brings together STEM intervention program directions and administrators to share strategies and learn additional strategies used by similar programs. Other meetings of program directors are helpful but also must include those with authority to make changes that support advancing institutional change. The ADVANCE grant, sponsored by NSF, is another example where institutional change is the focus. We propose that funders continue to provide opportunities to organize STEM PDs to become effective change agents. We propose that new, or current meeting spaces for STEM PDs provide opportunities to discuss leadership and sustainability strategies in addition to improving the scholarship on intervention efficacy that will lead to more institutional support.

Examining the compelling narratives of STEM program directors provides insight that can inform senior administrators, STEM faculty, and leaders involved in STEM education transformation within higher education. Findings from this study lend evidence for wide institutional commitment in order for STEM interventions to have more success. Approaches that take into account institutionalization processes may be useful for STEM PDs in order to focus on ways their programs can become vital and supported parts of the institution. In particular, STEM PDs can incorporate strategies to achieve their aims of supporting educational and career training for under-represented students that also work toward institutionalizing their efforts [30]. In addition to strategies that STEM PDs can use to work toward institutionalization, it is pivotal that institutional leaders realize their responsibility in supporting program directors at their institution, which largely benefits the institution at large due to the positive effects programs have on students, including increased retention rates, sense of belonging, and career preparedness. The role of program 
directors has become critical in advancing talent in STEM that are in the institution's and the nation's best interests.

Author Contributions: Conceptualization, A.K.G., K.P.C. and S.H.; formal analysis, A.K.G. and K.P.C.; funding acquisition, S.H.; investigation, A.K.G. and K.P.C.; methodology, A.K.G. and K.P.C.; project administration, A.K.G., K.P.C. and S.H.; resources, S.H.; supervision, A.K.G. and S.H.; visualization, A.K.G. and K.P.C.; writing-original draft, A.K.G. and K.P.C.; writing-review and editing, A.K.G., K.P.C. and S.H. All authors have read and agreed to the published version of the manuscript.

Funding: This research was funded by National Institute of General Medical Sciences, grant number R01 GMO71968-01 and R01 GMO71968-05.

Conflicts of Interest: The authors declare no conflict of interest.

Appendix A

Table A1. Institutions in Study.

\begin{tabular}{|c|c|c|c|c|c|}
\hline $\begin{array}{l}\text { Institution } \\
\text { Pseudonym }\end{array}$ & Control & MSI Status & Classification & Efficiency Scores & Interviewees \\
\hline $\begin{array}{c}\text { University of the } \\
\text { Southeast }\end{array}$ & Public & $\mathrm{N} / \mathrm{A}$ & $\begin{array}{c}\text { Doctoral Universities: } \\
\text { Highest Research Activity }\end{array}$ & 0.79 All STEM & $\begin{array}{c}4 \text { Staff; } \\
3 \text { Faculty/Staff }\end{array}$ \\
\hline $\begin{array}{l}\text { Atlantic Southern } \\
\text { State University }\end{array}$ & Public & HBCU & $\begin{array}{l}\text { Master's Colleges and } \\
\text { Universities: Medium } \\
\text { Programs }\end{array}$ & $\begin{array}{c}\text { 0.89 American Indian } \\
\text { 0.84 Black } \\
\text { 0.52 Latinx }\end{array}$ & $\begin{array}{c}2 \text { Staff; } \\
3 \text { Faculty/Staff }\end{array}$ \\
\hline $\begin{array}{l}\text { Southeast State } \\
\text { University }\end{array}$ & Public & HSI & $\begin{array}{l}\text { Doctoral Universities: } \\
\text { Highest Research Activity }\end{array}$ & $\begin{array}{c}\text { 0.82 Latinx } \\
0.53 \text { Black } \\
0.35 \text { American Indian }\end{array}$ & $\begin{array}{c}3 \text { Staff; } \\
3 \text { Faculty/Staff }\end{array}$ \\
\hline $\begin{array}{l}\text { Northern } \\
\text { Mountain } \\
\text { University }\end{array}$ & Public & $\mathrm{N} / \mathrm{A}^{* *}$ & $\begin{array}{l}\text { Doctoral Universities: } \\
\text { Higher Research Activity }\end{array}$ & $\begin{array}{c}\text { 0.94 American Indian } \\
\text { 0.75 Latinx } \\
0.25 \text { Black }\end{array}$ & $\begin{array}{c}4 \text { Staff; } \\
1 \text { Faculty/Staff }\end{array}$ \\
\hline $\begin{array}{l}\text { West Coast State } \\
\text { University }\end{array}$ & Public & HSI & $\begin{array}{c}\text { Master's Colleges and } \\
\text { Universities: Larger } \\
\text { Programs }\end{array}$ & $\begin{array}{c}0.83 \text { Latinx } \\
0.37 \text { American Indian } \\
\text { 0.27 Black }\end{array}$ & $\begin{array}{c}5 \text { Staff; } \\
1 \text { Faculty/Staff }\end{array}$ \\
\hline $\begin{array}{l}\text { East Coast State } \\
\text { University }\end{array}$ & Public & HSI & $\begin{array}{l}\text { Doctoral Universities: } \\
\text { Higher Research Activity }\end{array}$ & 0.81 All STEM & 3 Faculty/Staff \\
\hline $\begin{array}{l}\text { Mid-Atlantic } \\
\text { University }\end{array}$ & Private & $\mathrm{HBCU}$ & $\begin{array}{l}\text { Doctoral Universities: } \\
\text { Higher Research Activity }\end{array}$ & $\begin{array}{c}\text { 0.76 Black } \\
\text { 0.40 Latinx } \\
\text { 0.35 American Indian }\end{array}$ & 5 Staff \\
\hline $\begin{array}{l}\text { Central Plains } \\
\text { State University }\end{array}$ & Public & $\mathrm{N} / \mathrm{A}^{* *}$ & $\begin{array}{l}\text { Doctoral Universities: } \\
\text { Higher Research Activity }\end{array}$ & $\begin{array}{c}\text { 0.96 American Indian } \\
\text { 0.44 Latinx } \\
0.35 \text { Black }\end{array}$ & $\begin{array}{c}1 \text { Staff; } \\
2 \text { Faculty/Staff }\end{array}$ \\
\hline $\begin{array}{l}\text { Southern Private } \\
\text { University }\end{array}$ & Private & HSI & $\begin{array}{c}\text { Master's Colleges and } \\
\text { Universities: Larger } \\
\text { Programs }\end{array}$ & $\begin{array}{c}\text { 0.65 Latinx } \\
0.35 \text { American Indian } \\
0.12 \text { Black }\end{array}$ & 6 Faculty/Staff \\
\hline $\begin{array}{l}\text { Midwest State } \\
\text { University }\end{array}$ & Public & $\mathrm{N} / \mathrm{A}$ & $\begin{array}{c}\text { Doctoral Universities: } \\
\text { Highest Research Activity }\end{array}$ & 0.75 All STEM & $\begin{array}{c}3 \text { Staff; } \\
1 \text { Faculty/Staff }\end{array}$ \\
\hline
\end{tabular}

** High population of Native American students (50). 
Table A2. Interview Protocol.

\section{Exploring the Normative Contexts of Productive Institutions and Interventions}

(Protocol for Program Directors)

1. Please state your name and title for the recording. How long have you been at this institution? What is/are your role(s) on this campus now? What is your specific role within your STEM support program?
a. How would you describe your work with STEM undergraduates?
b. In what ways do you feel supported by colleagues on this campus?
c. In what ways do you feel a lack of support?
d. How did you become involved in the program? (RQ1)

2. We chose to visit this campus because our analysis showed you are among the most efficient institutions in producing (group) STEM degrees across the nation. What would you say contributes to this level of productivity?

a. Probes: policies, programs, structures, processes, incentives, strategic plans, broader institutional commitment to teaching and learning, broader institutional commitment to diversity, institutional coordination or collaboration.

b. How would you characterize the culture for innovation in STEM teaching and learning at this institution?

3. Tell me about your program: what was the identified need your program was established to meet?

a. What types of support does your program offer your students? (i.e., Academic, financial, social, emotional, mentoring, professional development) (RQ1)

b. Probes: number of years in existence, program goals, program structure (i.e., number of staff, part-time, full-time, student workers, etc.), number of students served per year, number of URM students served per year, type of students targeted, recruitment and admission procedures.

4. What are common obstacles your program faces when serving students? What type and/or level of resource support do you receive for your program? (RQ2)

a. Financial: grants, institutional, private-giving.

b. Other: academic, staffing, physical space.

c. (If grant-funded) What will happen when your grant ends? In what ways is your program being institutionalized?

5. In what ways has your program contributed to student success in STEM at your institution? (RQ1)

a. Probe: retention and graduation rates; institutionalized practices; partnerships with community.

b. Probe: how do you measure the program's impact?

c. What would you identify as one key promising practice connected with your program's support of STEM students which makes you unique from other programs?

6. Who do you work most closely with in terms of improving STEM student outcomes?

a. Probes: faculty, other program directors on campus, external constituents.

7. In what ways has working with students in your program shaped how you identify STEM talent and define student success? (RQ5)

a. Probe: how would you describe your role as a mentor?

b. How do your interactions with students facilitate their achievement?

8. In what ways can this campus be doing even better with regard to STEM participation and productivity?

Table A3. Program Directors in the Study.

\begin{tabular}{|c|c|c|c|}
\hline Institution & Department & Position & $\begin{array}{l}\text { Years at } \\
\text { Institution }\end{array}$ \\
\hline West Coast State University & Academic Affairs & $\begin{array}{l}\text { Director of Academic Success and Learning } \\
\text { Services-Supervises STEM Tutoring Center }\end{array}$ & $\mathrm{N} / \mathrm{A}$ \\
\hline West Coast State University & Engineering & Director of Engineering Program & $\mathrm{N} / \mathrm{A}$ \\
\hline West Coast State University & Engineering & $\begin{array}{l}\text { Associate Dean for Research in College } \\
\text { of Engineering }\end{array}$ & $\mathrm{N} / \mathrm{A}$ \\
\hline West Coast State University & Academic Affairs & $\begin{array}{c}\text { Associate Provost in Academic Affairs-advises on } \\
\text { all STEM curriculum }\end{array}$ & $\mathrm{N} / \mathrm{A}$ \\
\hline West Coast State University & Academic Affairs & $\begin{array}{l}\text { Associate Vice President for Research-coordinates } \\
\text { effort of getting institutional STEM grants }\end{array}$ & $\mathrm{N} / \mathrm{A}$ \\
\hline
\end{tabular}


Table A3. Cont.

\begin{tabular}{|c|c|c|c|}
\hline Institution & Department & Position & $\begin{array}{c}\text { Years at } \\
\text { Institution }\end{array}$ \\
\hline West Coast State University & Biology & $\begin{array}{l}\text { Professor and Director of Science Program geared } \\
\text { towards URM and first-generation students }\end{array}$ & 10 years \\
\hline Southeast State University & Earth and Environment & $\begin{array}{c}\text { Associate Professor and Undergraduate Program } \\
\text { Director for Geoscience Program and Science } \\
\text { Education Program }\end{array}$ & 21 years \\
\hline Southeast State University & Academic Affairs & $\begin{array}{l}\text { Director of Center for Teaching-supports STEM } \\
\text { curriculum and pedagogy }\end{array}$ & 4 years \\
\hline Southeast State University & Math & Director of Math Program & 17 years \\
\hline Southeast State University & Academic Affairs & STEM Coordinator & $\mathrm{N} / \mathrm{A}$ \\
\hline Southeast State University & $\begin{array}{l}\text { Computing and } \\
\text { Information Sciences }\end{array}$ & $\begin{array}{l}\text { Director of School of Computing and } \\
\text { Information Sciences }\end{array}$ & $\mathrm{N} / \mathrm{A}$ \\
\hline Southeast State University & Psychology & $\begin{array}{c}\text { Professor and Program Director of } \\
\text { nationally-funded Training Fellowship Program for } \\
\text { URM students }\end{array}$ & 15 years \\
\hline Southeast State University & Biology & Professor of Quantifying Biology & 30 years \\
\hline Mid-Atlantic University & $\begin{array}{l}\text { Academic Affairs and } \\
\text { Math (formerly) }\end{array}$ & Director of STEM Program & 8 years \\
\hline Mid-Atlantic University & Academic Affairs & Associate Provost for Undergraduate Studies & 9 years \\
\hline Mid-Atlantic University & Academic Affairs & $\begin{array}{l}\text { Director of Orientation and Transition in } \\
\text { Undergraduate Studies }\end{array}$ & 4 years \\
\hline Mid-Atlantic University & Academic Affairs & $\begin{array}{c}\text { Director of Advising Services in the Office of } \\
\text { Undergraduate Studies }\end{array}$ & 10 years \\
\hline Mid-Atlantic University & $\begin{array}{l}\text { Engineering, Architecture, } \\
\text { and Computer Sciences }\end{array}$ & $\begin{array}{l}\text { Director of Undergraduate Studies for the College of } \\
\text { Engineering, Architecture and Computer Sciences }\end{array}$ & 13 years \\
\hline $\begin{array}{l}\text { Northern Mountain } \\
\text { University }\end{array}$ & Academic Affairs & President & 9 years \\
\hline $\begin{array}{l}\text { Northern Mountain } \\
\text { University }\end{array}$ & Academic Affairs & Executive Director for Environmental Professionals & $\mathrm{N} / \mathrm{A}$ \\
\hline $\begin{array}{l}\text { Northern Mountain } \\
\text { University }\end{array}$ & Academic Affairs & Director of Center for Science Teaching and Learning & 2 years \\
\hline $\begin{array}{l}\text { Northern Mountain } \\
\text { University }\end{array}$ & Biology & $\begin{array}{l}\text { Full Professor and Director of Initiative to Maximize } \\
\text { Student Potential }\end{array}$ & 16 years \\
\hline $\begin{array}{l}\text { Northern Mountain } \\
\text { University }\end{array}$ & Environmental Science & $\begin{array}{l}\text { Director of Education for Environmental Research } \\
\text { and Director of Biodiversity Center }\end{array}$ & 12 years \\
\hline Central Plains State University & Geology & $\begin{array}{l}\text { Professor of Geology and Department Head in the } \\
\text { School of Geology }\end{array}$ & $\mathrm{N} / \mathrm{A}$ \\
\hline Central Plains State University & Engineering & Head of Civil and Environmental Engineering & 36.5 years \\
\hline Central Plains State University & Math & Clinical Assistant Professor of Math & 15 years \\
\hline East Coast State University & Academic Affairs & Director of the Learning Center & 7 years \\
\hline East Coast State University & Psychology & $\begin{array}{c}\text { Professor of Psychology and Director of Biomedical } \\
\text { Research Support Program }\end{array}$ & 11 years \\
\hline East Coast State University & Academic Affairs & $\begin{array}{c}\text { Associate Dean and Director of Academic } \\
\text { Foundations Center which houses the Student } \\
\text { Support Services }\end{array}$ & 21 years \\
\hline
\end{tabular}


Table A3. Cont.

\begin{tabular}{|c|c|c|c|}
\hline Institution & Department & Position & $\begin{array}{l}\text { Years at } \\
\text { Institution }\end{array}$ \\
\hline Southern Private University & Math & Associate Professor of Mathematics & 7 years \\
\hline Southern Private University & Academic Affairs & $\begin{array}{c}\text { Director of Academic Counseling and } \\
\text { Support Programs }\end{array}$ & 4 years \\
\hline Southern Private University & Academic Affairs & Director of Instructional and Emerging Technology & 3 years \\
\hline Southern Private University & Student Affairs & $\begin{array}{l}\text { Director of Residential Life-includes Natural } \\
\text { Science Living Learning Community }\end{array}$ & 2 years \\
\hline Southern Private University & Natural Sciences & $\begin{array}{c}\text { Associate Dean for Faculty Development in the } \\
\text { Natural Sciences and Director of Undergraduate } \\
\text { Research for students in the School of } \\
\text { Natural Sciences }\end{array}$ & 30 years \\
\hline Southern Private University & Academic Affairs & Director of the College Assistance Program & 22 years \\
\hline Midwest State University & Chemistry & $\begin{array}{c}\text { Director of Undergraduate Studies in Chemistry and } \\
\text { Chemistry Professor }\end{array}$ & 16 years \\
\hline Midwest State University & Academic Affairs & $\begin{array}{l}\text { Director of the Multicultural Center for } \\
\text { Academic Excellence }\end{array}$ & $\mathrm{N} / \mathrm{A}$ \\
\hline Midwest State University & Engineering & $\begin{array}{l}\text { Associate Professor of Electrical and } \\
\text { Computer Engineering }\end{array}$ & 34 years \\
\hline Midwest State University & Academic Affairs & Program Director of the North Star STEM Alliance & 8 years \\
\hline University of the Southeast & Physics and Astronomy & $\begin{array}{l}\text { Director of Undergraduate Laboratories in the } \\
\text { Department of Physics and Astronomy }\end{array}$ & 15 years \\
\hline University of the Southeast & Biology & Senior Lecturer and Advisor for Biology & 10 years \\
\hline University of the Southeast & Arts and Sciences & $\begin{array}{c}\text { Associate Professor of African American and } \\
\text { Diaspora Studies and the Director of Faculty } \\
\text { Diversity Initiatives in the College of Arts } \\
\text { and Sciences }\end{array}$ & 11 years \\
\hline University of the Southeast & $\begin{array}{l}\text { Environmental Sciences } \\
\text { and Public Health }\end{array}$ & $\begin{array}{c}\text { Professor of Environmental Sciences and } \\
\text { of Engineering }\end{array}$ & 30 years \\
\hline University of the Southeast & $\begin{array}{l}\text { Nursing, Public Affairs, } \\
\text { and Dentistry }\end{array}$ & $\begin{array}{l}\text { Professor in School of Nursing and Director of } \\
\text { Multicultural Affairs for Nursing and Diversity } \\
\text { Champion for Dentistry and Public Affairs }\end{array}$ & 12 years \\
\hline $\begin{array}{l}\text { Atlantic Southern State } \\
\text { University }\end{array}$ & Neuroscience & $\begin{array}{l}\text { Director of Biomedical Research Infrastructure } \\
\text { Center and Professor of Neuroscience }\end{array}$ & 9 years \\
\hline $\begin{array}{l}\text { Atlantic Southern State } \\
\text { University }\end{array}$ & Chemistry & $\begin{array}{l}\text { Chief Research Officer and Director of Science } \\
\text { Initiatives and Associate Professor of Chemistry }\end{array}$ & $\mathrm{N} / \mathrm{A}$ \\
\hline $\begin{array}{l}\text { Atlantic Southern State } \\
\text { University }\end{array}$ & Academic Affairs & $\begin{array}{l}\text { Executive Director of the Center for Design } \\
\text { Innovation-Biology Classes }\end{array}$ & 1 year \\
\hline $\begin{array}{l}\text { Atlantic Southern State } \\
\text { University }\end{array}$ & $\begin{array}{l}\text { Behavioral Sciences and } \\
\text { Social Work }\end{array}$ & $\begin{array}{c}\text { Director of the Center for Excellence in Teaching and } \\
\text { Learning and Associate Professor of Behavioral } \\
\text { Sciences and Social Work }\end{array}$ & 5 years \\
\hline
\end{tabular}


Table A4. Codebook.

Code Sub-Themes

Monetary Support

Financial support for STEM program implementation. Sources of monetary support included: federal grants, private foundation grants, federal funds, state funds for public institutions, private industry, and college

budgets, including dean's discretionary funds, funds

from the provost's office, and funds raised by university development offices.

Types of Support Received

Non-Monetary Support
Tangible non-monetary resources and social capital provided to support STEM program implementation that are not financial. Some non-monetary sources of support frequently mentioned by program directors included: community support from local or state businesses, non-profit organizations, and tribes;

dedicated institutional agents, such as faculty and staf that served as allies; productive collaboration with other programs and offices on campus; support from senior leadership.

\section{Example}

"I think it's come up in the past, well, maybe we could get a bigger budget if we asked for it over here, but we've never wanted to because keeping the funding here keeps the math lab close to the math classes, and then our faculty, and we were just-we were scared that maybe if the funding came from somewhere else, that would tie it to the library where the writing center is, but we don't really want [our program] to be that far away from the math faculty and the math classes." -Program Director, Southern Private University

It really has to be bottom up to be successful. But it has to have top level support ... Because if you don't get the faculty committed to do it, it's never going to happen. I don't care how much money you throw at it. You can throw an infinite amount of funds and if the faculty aren't committed to doing it and aren't willing to change, it's not going to happen. So I see all these big programs across the country where people have thrown lots of money at trying to increase the numbers of underrepresented minorities in science... I feel like what we're doing is really having a pretty substantial impact and it's mostly because it's bottom up and the faculty are committed to making it work." -Program Director, University of the Southeast 
Table A4. Cont.

Demonstrate

Program's Efficacy

Continuously justifying why STEM program was a beneficial investment for the institution. Garnering this type of buy-in was especially necessary when

institutions were undergoing departmental evaluations or when institutional budgets became constrained.

Mobilizing others to support STEM program and STEM equity efforts more broadly. Bringing together individuals in different roles at the institution and

Coordinate and

Streamline Efforts

Key Strategies for Broadening Impact

列

Examples of efforts coordinated: introductory course

curricula and pedagogy, institutionalizing practices in

the event that an influential STEM PD left the

institution, streamlining funding sources for program.

Support for their labor as a necessity to achieve their

mission of serving students, especially those from

marginalized backgrounds. Financial or policy

Incentivize Support

for Labor

incentives to compensate or credit effort toward STEM

program and/or STEM equity efforts.

Consolidate Support from Leaders
Made a concerted effort to meet with deans at their institution and inform them about their programs
“The MEP programs that didn't survive what I know, and I can tell you personally, is that they were not able to demonstrate their efficacy. Here, we have a very strong assessment. So we're able to demonstrate why you HIPs [high impact practices] work and what did you do and how did you measure success, what is the data you collected, what is your interpretation? You become more credible."

-Program Director, West Coast State University

"I think on the back end, too, we communicate really well with the different departments. I have a meeting with the Dean of Students' office once a month. I also have met with the academic counselors and talked with them. I also am in constant contact with the Student Disability Services. We talk to each other and let them know what's going on with each of the students, like, are you having an issue with a student, and, "Oh, the student's been missing class." Is there something going on in their personal life? We communicate about those issues, too with the departments."

$$
\text { -Southern Private University }
$$

"So I think everyone agrees research is important, going to conferences is important, but the load disproportionately falls on the few who are willing to actually do that. I think everyone supports it and thinks it's a great idea, but we need to either spread that load evenly throughout the department or figure out a way to credit the time and effort it requires for it to fall on only a few faculty before we get burnt-out." -Program Director, Southern Private University

"I've gone to all the Deans, I've talked to all of them, told them who we are. The President is very well aware of us now. I asked for a promotional video four years ago, we're working on it now. So it's things like that, that you kind of have to like say, okay, 'We're here and we're helping you meet

your goal number six, which is to become the leading university serving tribes."

—Program Director Northern Mountain University 
Table A4. Cont.

Program Director: I see a lot of people promote it [active learning] saying that you can do this team based learning type of stuff in a class of 150

Program directors had moved past the hurdle of securing funding from grants but still had to face the challenges that came with implementing their

initiatives. The Director of the Geosciences Program at

Southeast State University was constrained by the institution's limited infrastructure, which did not support the active learning practices he sought to implement The institution's facilities were a rea barrier for efforts to improve STEM teaching and learning at Southeast State University.

Challenges Faced

Lack of Support from

Senior Administration board with program directors' efforts or did not share their goals, they could present serious challenges to the program's funding, visibility, institutionalization, and ultimately its survival.

Program directors repeatedly discussed the challenges that arose from not having enough funds to hire more staff. Being understaffed and underfunded was the norm for many, who learned to work around these

Being Understaffed/Underfunded to students. Several expressed concerns of burning out,

however, due to their heavy workloads, often over several years in their positions.
It's just not effective. I tried it last fall in a general physical geology course, and it just seemed like-with learning assistants that part was awesome, but you had this big class-you had this big theatre-type sitting with no aisle in the middle, and you couldn't get to help the students. It was just too difficult.

Interviewer: So, the infrastructure of the actual classroom space can be a barrier...?

Program Director: Yes that's right. And so often the classrooms generally are not designed for this. It's very rare to get a classroom that just has tables in it. Almost-there is always the fixed desk type of thing, and so if you want to have students actually doing problems, they don't have that workspace.

-Program Director, Southeast State University

"I guess that's where it comes with administrative support. If I wasn't the one in this position ... if the person in this position supported that kind of thing, rapid change that doesn't have to go through committee and process, perhaps that too would help change to occur at a much more

rapid rate ... you have to have support at the right levels." -Program Director, Mid-Atlantic University

"We can always use more staff. [Laughter]. If you do the calculation between the ratio of students to a counselor, it's still quite high at about 150 to 160 students per counselor, so that ends up being high because not only do they see students all day, they also have some administrative functions that they do as well. It's always great to have more counselors on staff, but we are limited to four. That's one obstacle. The other obstacle is also that the trend has been that a lot of the students have a lot more mental baggage or emotional baggage that come with them, and even though our counselors are of varied backgrounds in their degrees, they are not social workers ... What other obstacles? We could always use money to do lots of things, to make things bigger or greater." - Program Director, East Coast State University 


\section{References}

1. Linley, J.L.; George-Jackson, C.E. Addressing Underrepresentation in STEM Fields through Undergraduate Interventions. New Dir. Stud. Serv. 2013, 144, 97-102. [CrossRef]

2. Granovskiy, B. Science, Technology, Engineering, and Mathematics (STEM) Education: An Overview; Congressional Research Service: Washington, DC, USA, 2018.

3. Rincon, B.E.; George-Jackson, C.E. STEM intervention programs: Funding practices and challenges. Stud. High. Educ. 2016, 41, 429-444. [CrossRef]

4. Baber, L.D. Considering the Interest-Convergence Dilemma in STEM Education. Rev. High. Educ. 2015, 38, 251-270. [CrossRef]

5. Estrada, M.; Burnett, M.; Campbell, A.G.; Campbell, P.B.; Denetclaw, W.F.; Gutiérrez, C.G.; Hurtado, S.; John, G.H.; Matsui, J.; McGee, R.; et al. Improving Underrepresented Minority Student Persistence in STEM. CBE-Life Sci. Educ. 2016, 15, es5. [CrossRef] [PubMed]

6. Hurtado, S.; White-Lewis, D.; Norris, K. Advancing inclusive science and systemic change: The convergence of national aims and institutional goals in implementing and assessing biomedical science training. BMC Proc. 2017, 11, 1-13. [CrossRef] [PubMed]

7. Kezar, A.; Lester, J. Supporting Faculty Grassroots Leadership. Res. High. Educ. 2009, 50, 715-740. [CrossRef]

8. Lester, J.; Kezar, A.J. Understanding the Formation, Functions, and Challenges of Grassroots Leadership Teams. Innov. High. Educ. 2012, 37, 105-124. [CrossRef]

9. Kezar, A. Grassroots leadership: Encounters with power dynamics and oppression. Int. J. Qual. Stud. Educ. 2011, 24, 471-500. [CrossRef]

10. May, D.B.; Susskind, D.; Shapiro, N.S. Faculty Grassroots Leadership in Science Education Reform: Considerations for Institutional Change, Culture, and Context. Creat. Educ. 2013, 4, 22-31. [CrossRef]

11. Kezar, A.; Bertram Gallant, T.; Lester, J. Everyday people making a difference on college campuses: The tempered grassroots leadership tactics of faculty and staff. Stud. High. Educ. 2011, 36, 129-151. [CrossRef]

12. Stanton-Salazar, R.D. A Social Capital Framework for the Study of Institutional Agents and Their Role in the Empowerment of Low-Status Students and Youth. Youth Soc. 2011, 43, 1066-1109. [CrossRef]

13. Bensimon, E.M.; Dowd, A.C.; Stanton-Salazar, R.; Dávila, B.A. The Role of Institutional Agents in Providing Institutional Support to Latinx Students in STEM. Rev. High. Educ. 2019, 42, 1689-1721. [CrossRef]

14. Birnbaum, R. How Academic Leadership Works: Understanding Success and Failure in the College Presidency; ERIC: Washington, DC, USA, 1992.

15. Cooper, J.E.; Pagotto, L. Developing Community College Faculty as Leaders. New Dir. Community Coll. 2003, 123, 27-37. [CrossRef]

16. Stone, G.L.; Lucas, J. Disciplinary counseling in higher education: A neglected challenge. J. Couns. Dev. 1994, 72, 234-238. [CrossRef]

17. Hrabowski III, F.A. Institutional Change in Higher Education: Innovation and Collaboration. Peabody J. Educ. 2014, 89, 291-304. [CrossRef]

18. George, C.E.; Castro, E.L.; Rincon, B. Investigating the Origins of STEM Intervention Programs: An Isomorphic Analysis. Stud. High. Educ. 2019, 44, 1645-1661. [CrossRef]

19. Russ, R.S. Epistemology of science vs. epistemology for science. Sci. Educ. 2014, 98, 388-396. [CrossRef]

20. Titus, M.A.; Eagan, K. Examining Production Efficiency in Higher Education: The Utility of Stochastic Frontier Analysis. High. Educ. Handb. Theory Res. 2016, 31, 441-512.

21. Eagan, M.K., Jr. Moving beyond Frontiers: How Institutional Context Affects Degree Production and Student Aspirations in STEM; ERIC: Washington, DC, USA, 2010.

22. Malik, S.K.; Rizvi, S.A. Information Extraction Using Web Usage Mining, Web Scrapping and Semantic Annotation. In Proceedings of the 2011 International Conference on Computational Intelligence and Communication Networks, Gwalior, India, 7-9 October 2011; pp. 465-469. [CrossRef]

23. Stake, R.E. Multiple Case Study Analysis; Guilford Press: New York, NY, USA, 2005.

24. Corbin, J.; Strauss, A. Basics of Qualitative Research: Techniques and Procedures for Developing Grounded Theory; Sage Publications: Thousand Oaks, CA, USA, 2014.

25. Birks, M.; Chapman, Y.; Francis, K. Memoing in qualitative research: Probing data and processes. J. Res. Nurs. 2008, 13, 68-75. [CrossRef]

26. Fernald, D.H.; Duclos, C.W. Enhance your team-based qualitative research. Ann. Fam. Med. 2005, 3, 360-364. [CrossRef] [PubMed]

27. White, D.E.; Oelke, N.D.; Friesen, S. Management of a large qualitative data set: Establishing trustworthiness of the data. Int. J. Qual. Methods 2012, 11, 244-258. [CrossRef]

28. Abell, S.K.; Lederman, N.G. Research on Science Education; Lawrence Erlbaum Associates: Mahwah, NJ, USA, 2007.

29. Carlisle, D.L.; Weaver, G.C. STEM education centers: Catalyzing the improvement of undergraduate STEM education. Int. J. STEM Educ. 2018, 5, 1-21. [CrossRef] [PubMed]

30. Cobian, K.P.; Ramos, H.V. A cross-case analysis of developing program sustainability and institutionalization in early stages of a multisite biomedical student diversity initiative. BMC Med. Educ. 2021, 21, 1-17. [CrossRef] [PubMed] 